Годишник Телекомуникации 2020, том 7, с. 71-81

Yearbook Telecommunications 2020, vol. 7, p. 71-81

eISSN 2534-854X

https://telecommunications.nbu.bg/bg/godishnik-telekomunikacii

DOI: https://doi.org/10.33919/YTelecomm.20.7.9

\title{
MODELLING AND SIMULATION OF ARTIFICIAL NEURAL NETWORKS USING SOFTWARE SIMBRAIN
}

\author{
Yoana Ivanova
}

\begin{abstract}
This paper is considered to be a continuation of a previous publication devoted to tendencies in the applications of advanced technology solutions to strengthen the cybersecurity of critical infrastructure (Yearbook Telecommunications, vol. 6, 2019). The specificity of the research is related to tracing the evolution of artificial neural networks (ANN) from their establishment to their modelling and simulation. The theoretical framework involves a well-supported rationale by some practical examples of advanced methods of design and simulation of ANN using SIMBRAIN. These methods are applicable in Cognitive science and Robotics because of their contribution to scientific researches related to study of perceptions and behaviors, abilities of decision making, pattern recognition and morphological analysis and etc.
\end{abstract}

Keywords: artificial neural networks, evolution, digitization, modelling, simulation, perceptron, Braitenberg vehicles, backpropagation

\section{INTRODUCTION}

The remarkable progress in neural networks was the concept of a perceptron which was intended to be a pattern recognition device. Nowadays, perceptrons are widely used for encoding, recognition of signals from locators, speech recognition, driving a car, image compression and etc. There is a variety of mathematical models and algorithms for simulating artificial neural networks (ANN). In the simulated approach a designer can operate with multiple data and to use many more models of transmission and propagation even under the influence of complex environmental conditions [1]. Pattern recognition methods are applicable in many areas including cybersecurity and especially in its directions related to encryption and pattern matching of encrypted streams, as well as to analysing stenographic images and techniques.

In terms of their historical development ADALINE (Adaptive Linear Neuron or later Adaptive Linear Element) is the early single-layer neural network which was developed by Professor Bernard Widrow and his graduate student Ted Hoff at Stanford University in 1960. In the standard perceptron the net is passed to the activation function and the function's output is used for adjusting the weights. Besides in the learning phase the weights are corrected according to the weighted sum of the inputs $[2,3]$.

In the mid-1960's Widrow presents an improved learning algorithm, called "punish/ reward" or "bootstrapping" for solving problems related to uncertainty about the error signal. The 1000-weight MADALINE I (Many ADALINE) was built and used in pattern recognition research in the early 1960's a. The constructions of ADELINE and MADALINE differ, because MADALINE has many more inputs and Adaline elements in the first layer, as well as multifarious fixed logic devices (AND, OR) and elements for voting in the second layer [4].

The main topic of study in the 1970's is associative memory, also known as autoassociation memory or an auto association network allowing a logical connecting by default between various input patterns on the base of sufficient similarity. Hopfield networks represent recurrent artificial neural networks, which are capable to remember data by observing a part of these data and in this sense they can act as an autoassociative memory [5].

As it is known, a Hopfield autoassociative memory network can "recover an original stored vector in the learning process of the Hopfield network". This process can be explained as follows [6]: 
- "when a single-layer recurrent network performs a sequential updating process, an input pattern is first applied to the network, and the output of the network is initialized accordingly";

- "the initialized output becomes the new, updated input through the feedback connections";

- $\quad$ "the first updated output is produced from the first input, and in turn acts as the second updated input through the feedback links to produce the second updated output";

- "the update process of the network is stopped when no new, updated responses are produced".

In 1974 the algorithm for training artificial neural networks through backward propagation of errors (backpropagation) was originally described by the scientist Paul J. Werbos, It was rediscovered in 1985 by David Everett Rumelhart, Geoffrey Hinton and Ronald J. Williams [7]. This common method calculates the gradient of a loss function regarding all the weights in the neural network.

The fundamental scientific concept of an artificial neuron as a mathematical thresholding function expressed by building logic gates and circuits simulating brain activity is described in Section 2 and illustrated by simulation models selected among the exemplary models built into SIMBRAIN. Section 3 contains the essence of the author's contribution to the task related to modelling and simulation of ANN.

\section{BASICS IN MODELLING A PERCEPTRON USING SIMBRAIN}

In 1943 McCulloch and Pitts initiated the modeling of artificial neural networks, proposing a mathematical reference model of a neuron as a binary threshold element which is shown in Fig. $1[8,9]$.

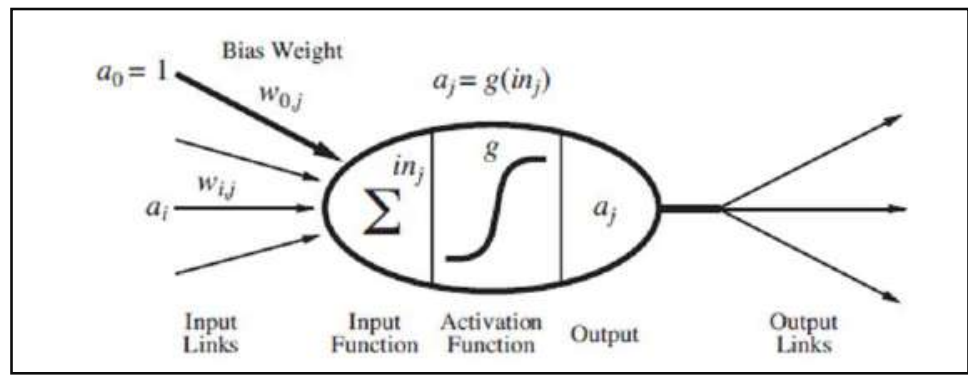

Fig. 1. A mathematical model of a neuron by McCulloch and Pitts.

The unit's output activation is $a_{j}$, where $a_{i}$ is the output activation of unit $i$ and $w_{i, j}$ is the weight on the link from unit $i$ to this unit. The activation function is designated by $g$.

$$
a_{j}=g\left(\sum_{i=0}^{n_{i=0}} w_{i, j} a_{i}\right)
$$

In other words, the aggregate input for an element is formed first. For this purpose, "the input values (signals) are multiplied by the weights of the connections and the results are summed". After that the processing element uses the specific network activation function (output function), which transforms the resulting aggregate input into the output (the output signal) of this element.

ANN are detailed and precise mathematical models of brain structures processing data by simulation a brain activity. The created by the author of this paper a $3 \mathrm{D}$ model of a brain is presented by an abstract visualization in Fig. 2 to emphasize the main concept of ANN. They are practically implemented by connected nodes built as chips that can be analog, digital or hybrid. 
Годишник Телекомуникации 2020, том 7, с. 71-81

Yearbook Telecommunications 2020, vol. 7, p. 71-81

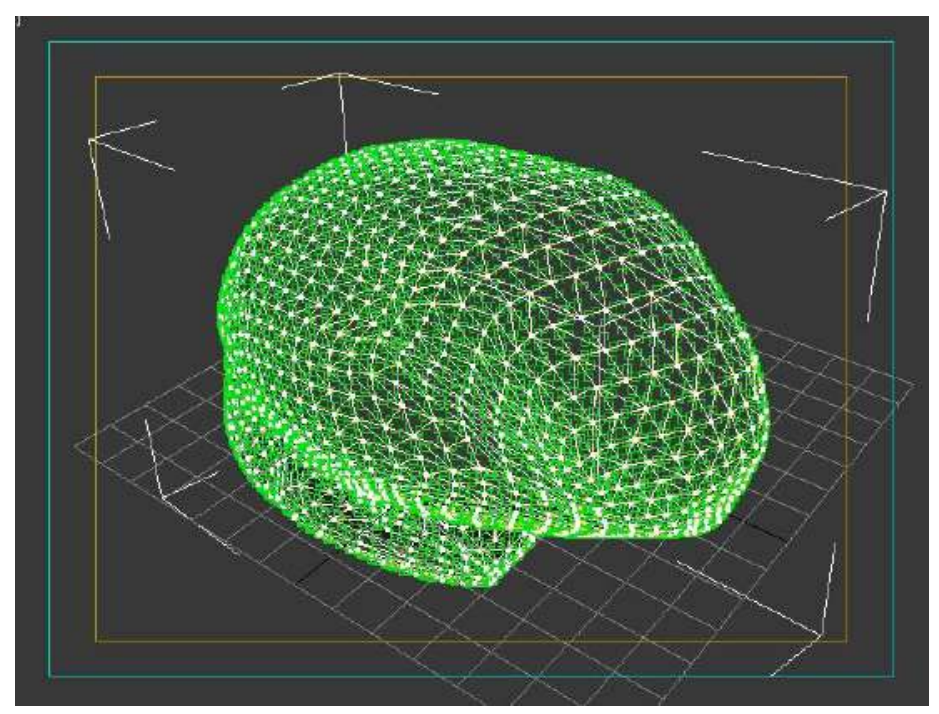

Fig. 2. An abstract 3D model of a brain built of artificial structures.

Practically many examples of contemporary artificial neural networks are related to the Braitenberg vehicles. The Italian-Austrian cyberneticist and neuroscientist Valentin von Braitenberg (Valentino Braitenberg) was a former director at the Max Planck Institute for Biological Cybernetics in Tübingen, Germany. The Braitenberg vehicles represent a kind of basic robots, which are described in his book „Vehicles: Experiments in Synthetic Psychology” [10] that has been is published in 1984 by the MIT Press, Cambridge.

The design of Vehicle 1 is the simplest compared to the other vehicles, which are described in the book. It is composed of two components - a motor and a sensor. Vehicle 8 is the most complex, because it is equipped with a ,lens eye”. 100 photocells are arranged 10x10 in a neat square. A lens is fitted on top of the array. The constructed in this way device represents a camera. Braitenberg vehicles are simple agents, whose movement is performed under the impact of environmental factors such as light. The simulation that is presented in this paper demonstrates movement similar to Vehicle $2 b$ that is known also as "the aggressive" vehicle. Vehicles $2 \mathrm{a}$ and $2 \mathrm{~b}$ are shown on Fig. 3.

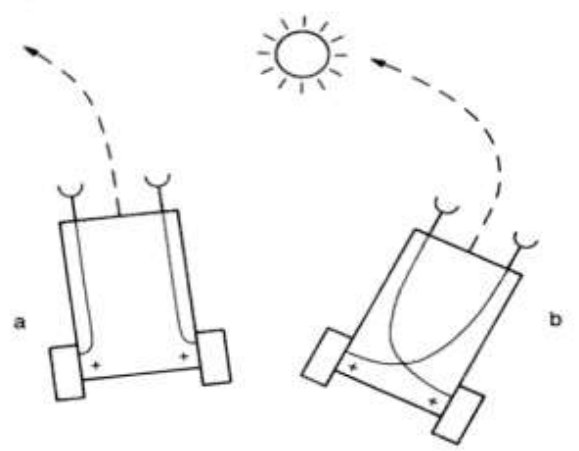

Fig. 3. Braitenberg vehicles $2 \mathrm{a}$ and $2 \mathrm{~b}$.

Vehicle 2a consists of two symmetric sensors (left and right). Each of the two sensors stimulates a wheel on the same side of the vehicle. "This vehicle represents a model of negative animal tropotaxis". Vehicle $2 b$ has the same two (left and right) symmetric sensors, but each one 
stimulates a wheel on the other side of the body. The rules for their movements are presented in the scheme of Fig. 4 [11].
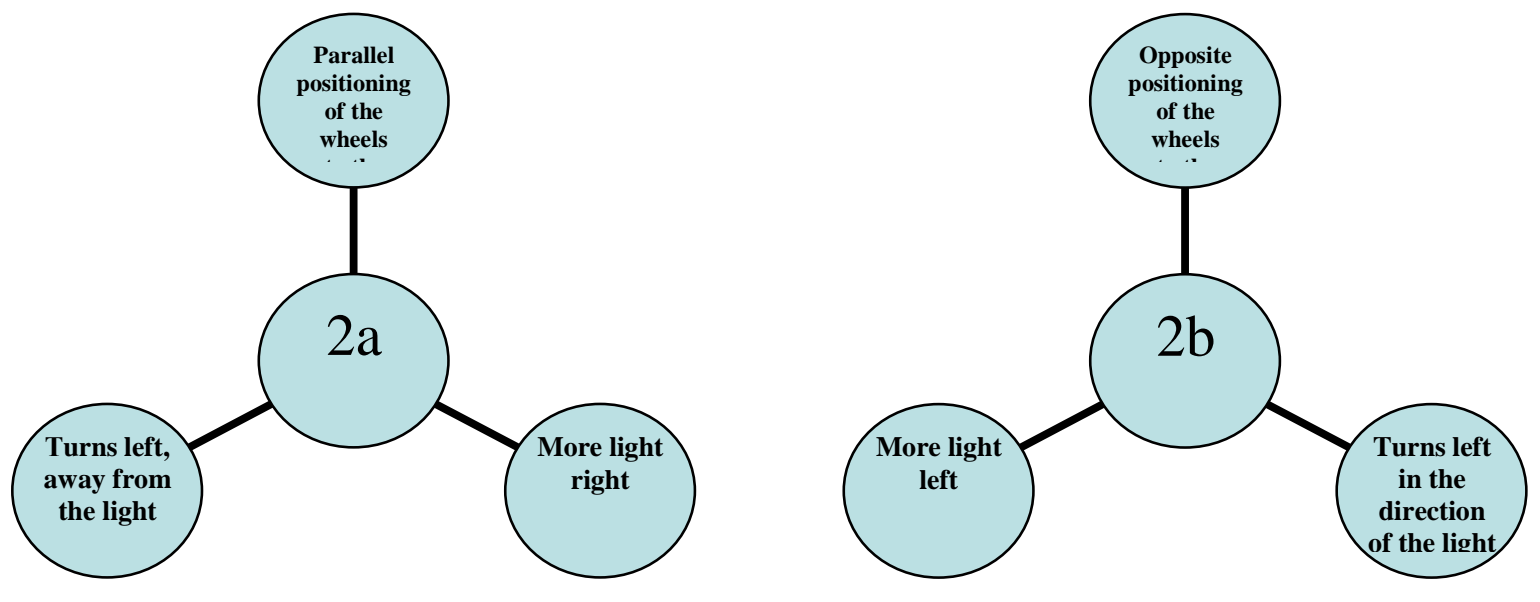

Fig. 4. Rules to which Breitenberg vehicles $2 \mathrm{a}$ and $2 \mathrm{~b}$ are subject.

SIMBRAIN is a very convenient Java based software for modelling, simulation and analysis of ANN that is compatible with Windows, Mac OS X, and Linux. Its workspace includes all simulation components required:

- networks - they are designed using a simple graphical interface;

- worlds - they interact with the network components by giving and/or receiving information. "OdorWorld" shown here simulates the abilities of the characters to move in a 2D environment.

- means and mechanisms for connecting the components - "couplings", scripting [12].

In Fig. 5 is shown an exemplary model of a perceptron designed using SIMBRAIN. The network can be simulated with randomly selected activation values.

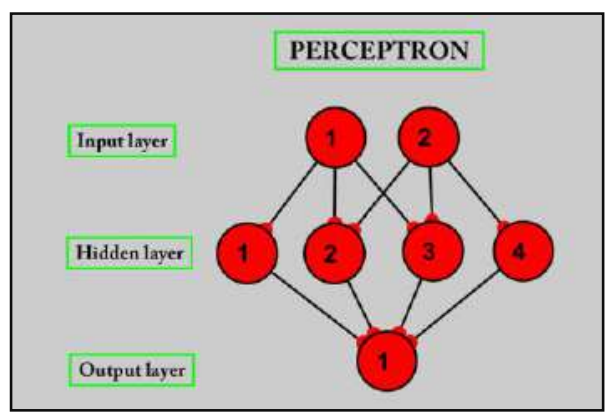

Fig. 5. A basic perceptron model created in SIMBRAIN.

In Fig. 6 is shown a network that demonstrates the movements of an agent (a vehicle or a character) to the left, if it is left sensor is activated by a source on its left, heading straight towards the source (a movable or an immovable entity). Respectively if the agent senses a source on its right, it will move to the right and straight towards the source. 
Годишник Телекомуникации 2020, том 7, с. 71-81

Yearbook Telecommunications 2020, vol. 7, p. 71-81

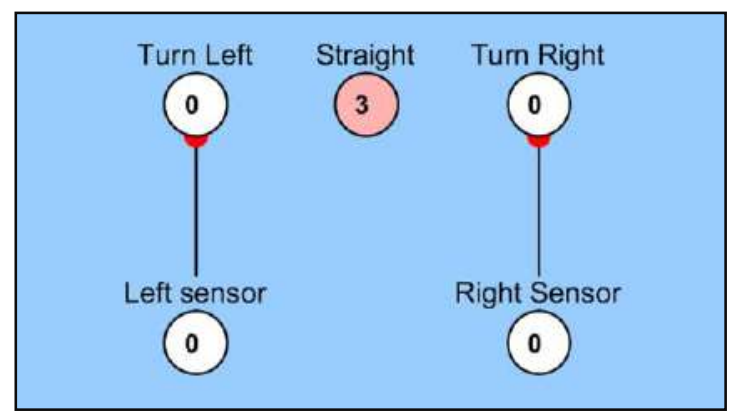

Fig. 6. A network that demonstrates the movements of an agent to the left or to the right.

A screenshot taken during the simulation performance is shown in Fig. 7.

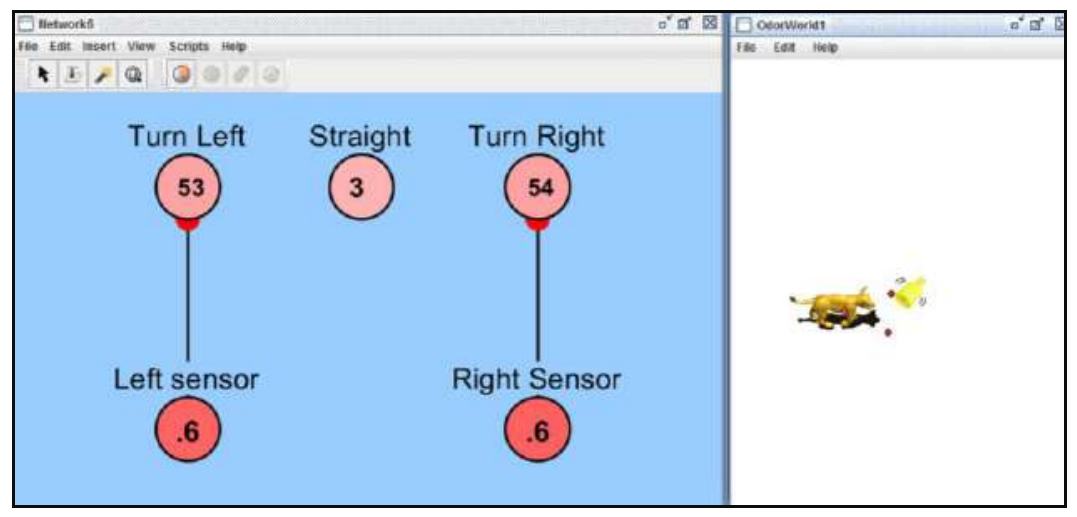

Fig. 7. The agent "lion" capturing a moving bell.

The basic examples, that are available in the software can be modified according to the specific objectives by adding neurons and synapses (connections) between them.

Another example with a higher level of complexity than the previous one is shown in Fig. 8 and Fig. 9. In this case the female character must make a choice between a pink flower that is situated on her left and a blue flower on her right. The behavior of the agent can be observed and analyzed by running the simulation at various positions of the entities.

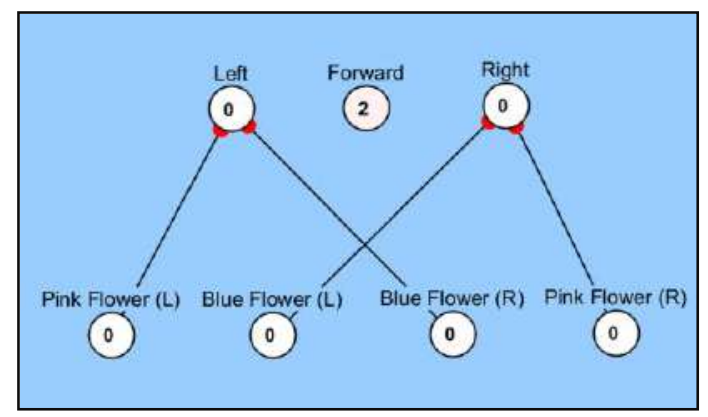

Fig. 8. A female character making a choice between two flowers in different colors. 


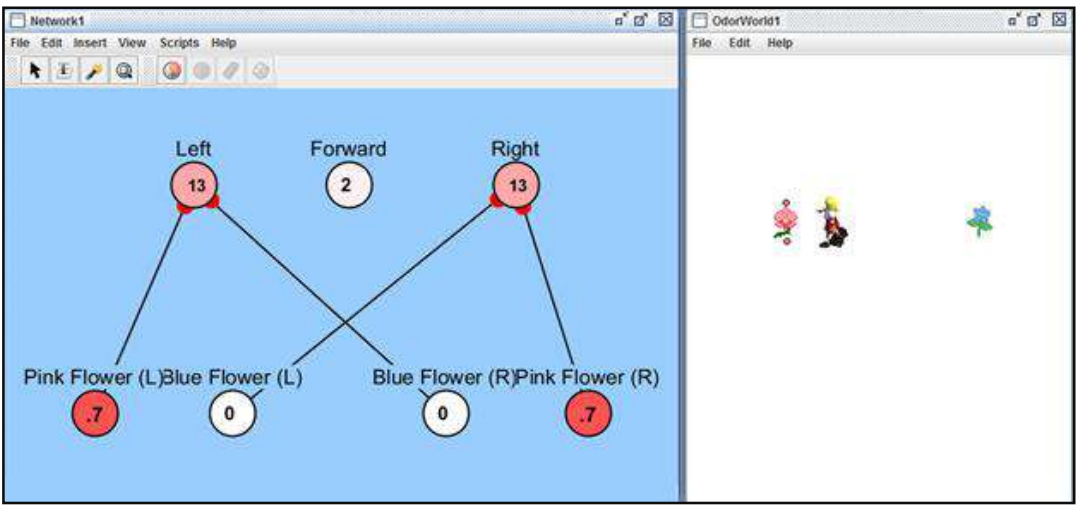

Fig. 9. A female character oriented towards the pink flower to her left.

\section{MODELLING A BACK PROPAGATION NEURAL NETWORK USING SIMBRAIN}

By the current experimental research the author aims to unscramble the process of pattern recognition by ANN with a back propagation of errors mentioned in the introductory part of the article. Besides, it highlights the connection between ES (Expert Systems) with AI (Artificial Intelligence) and digitization by innovative scanning technologies.

For example, the recognition method with a back propagation of errors is connected to digitization of 2D images and 3D objects which can be created using specialized software (CS Adobe Photoshop, Autodesk 3DS Max, Solid Works) or scanned by a special devices like 2D/3D scanners, digital cameras, photogrammetric applications and etc. On the other hand sound recognition is based on quantization that represents digitization of sound when a continuous analog wave is converted into discrete pulses that are read and measured regularly.

The experimental concept is based on a scientific training devoted to a backpropagation algorithm that aims creating a neural network for recognizing distinct patterns [13]. Two letters "p" and " $\mathbf{p}$ " in the word denoting the mathematical or Archimede's constant "pi" $(\boldsymbol{\pi}=\mathbf{3 , 1 4})$ are selected for the simulation because of the following reasons:

- an optimized matrix of the input scanner that reduces the algorithm complexity minimizing time and resources for running the simulation: fore letter $\mathbf{p}: 4 x 4$ sensors Number of Layers: 4; Input Layer: 16 neurons; Output Neurons: 2 neurons; Two Processing layers: 9 neurons.

- a possibility to improve the algorithm for number recognition - a scanning software like Input Scanner CSV can be used to draw and digitize more complex shapes like 3, 1 and 4 , because they require a matrix with a higher resolution $5 \times 5$. It is necessary to note that the number 4 can be drawn in two different ways (Fig. 10).

- the combination selected is suitable for a subsequent study related to sound recognition.

\subsection{Algorithm of modelling and simulation of ANN.} as follows:

The simulation process can be presented as an algorithm that includes a sequence of steps

1) prediction of all possible directions of each letter- in this case there is one true (value 1) and three false (value 0) directions per each letter and model them in Scanner CDV as it is shown in Fig. 11.

2) selecting Insert: New Network from the main toolbar - at this stage it is required to choose the type of the network (Insert Network: Backprop) and to make the settings for the number of layers and neurons (Fig. 12). 
Годишник Телекомуникации 2020, том 7, с. 71-81

Yearbook Telecommunications 2020, vol. 7, p. 71-81

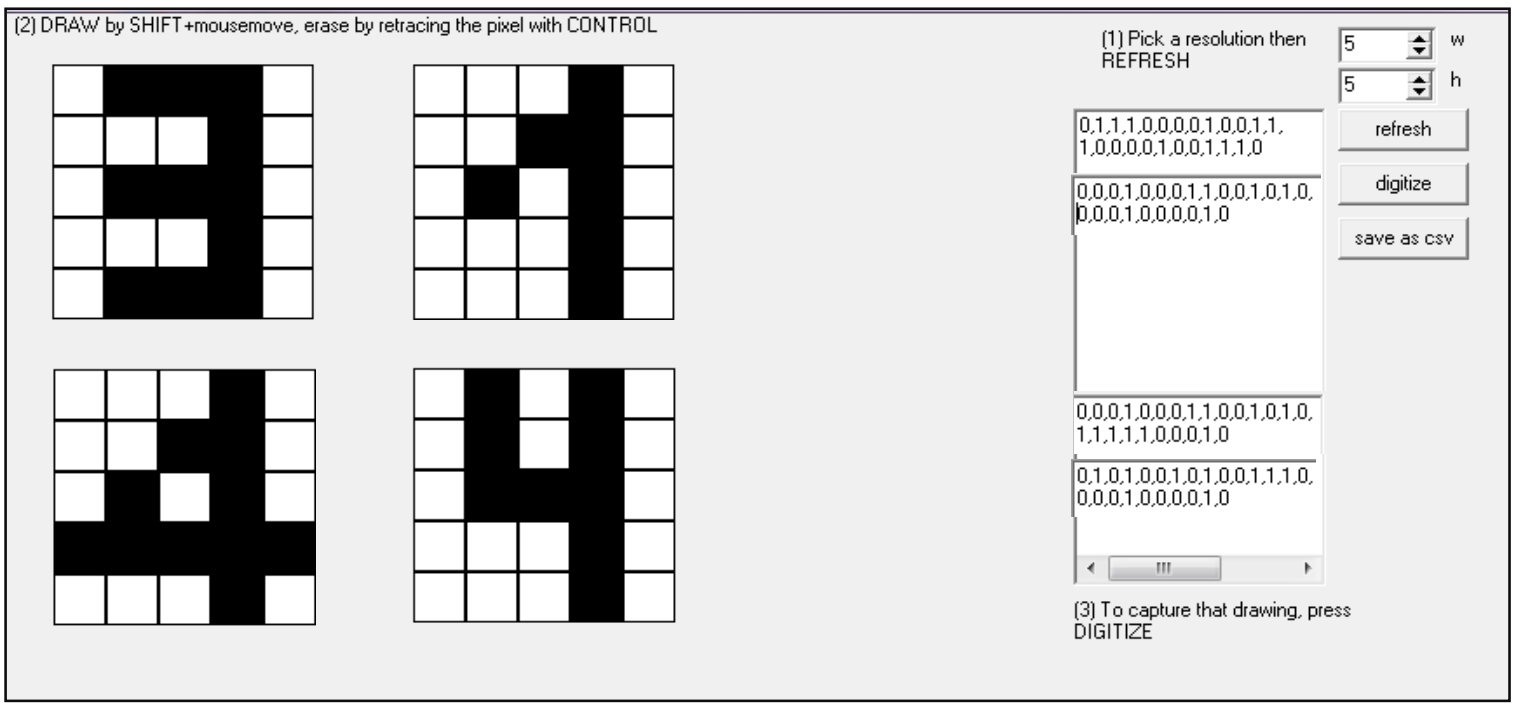

Fig. 10. A drawing of the number 3 in Scanner CSV.

3) renaming the four groups of layers - by a right click on each label and Rename Group and inserting the new name. The name of the network can be also changed.

4) editing and training the network - by a right click on the name of the network and Edit/ Train Backprop or View/ Edit Data: Edit Training Set. The two tables in Input and Target Data should contain 8 layers to insert the values 0 or 1 that are shown in Fig. 13. The tables that include the input and target data are presented in Fig. 13.

5) randomizing the network -there is a button Randomize network in the window Edit Backprop Network.

6) running the simulation - the final step is completed by pushing the button Iterate training until stop button pressed.

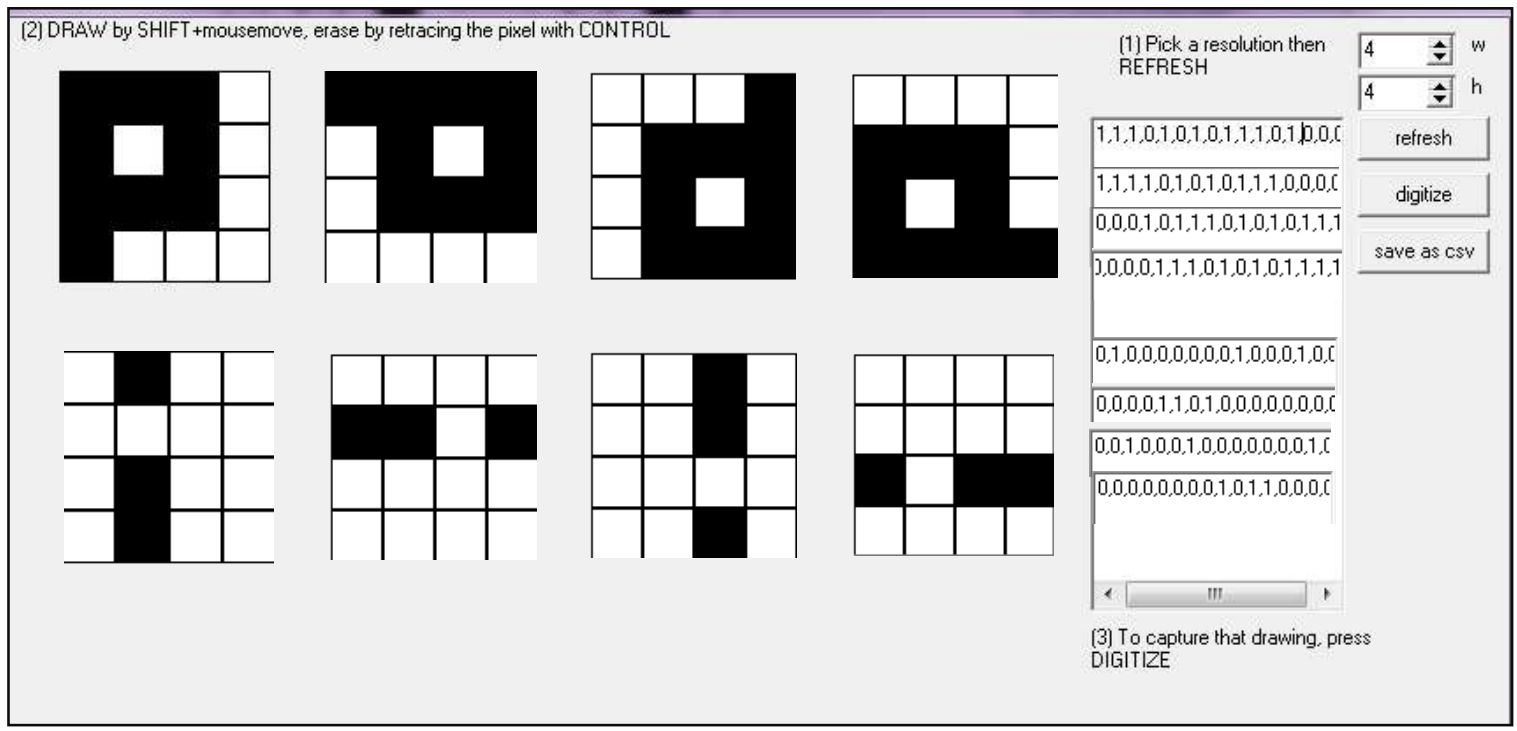

Fig. 11. Possible orientations of letters " p" and "i". 
YOANA IVANOVA

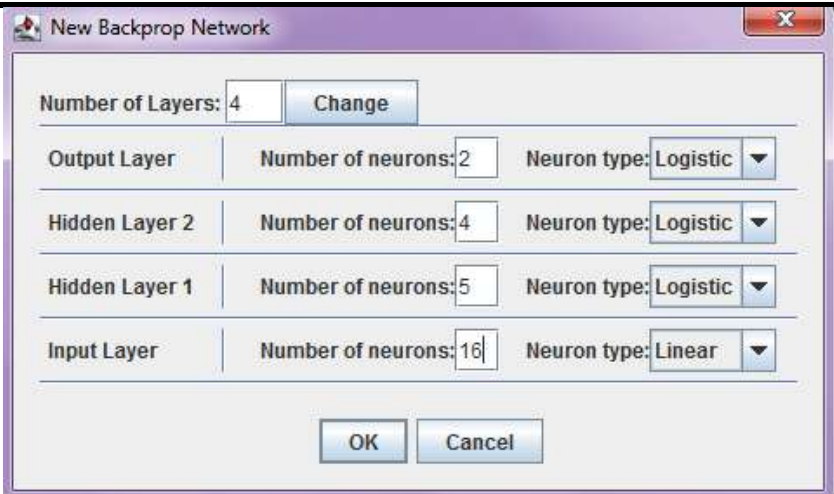

Fig. 12. The window for inserting the input parameters of ANN.

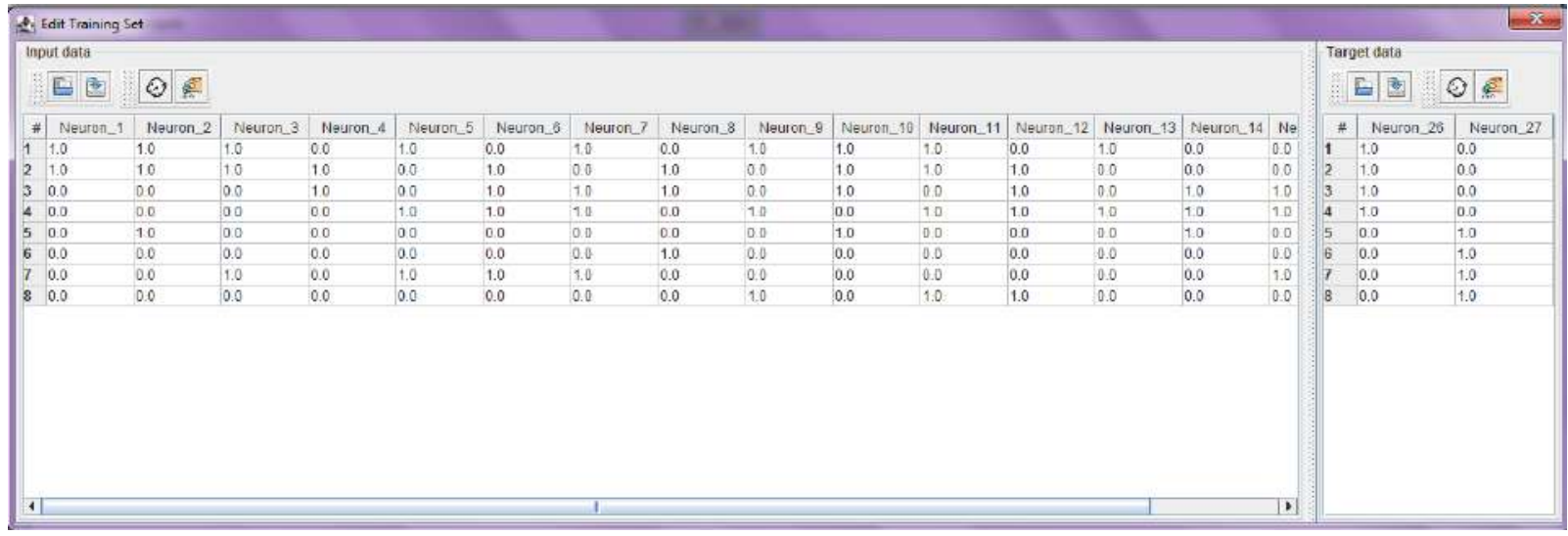

Fig. 13. The Input/Target data in the window for editing backprop network.

The result of the simulation with average duration $\mathrm{D}=5 \mathrm{~min}$ is presented in Fig. 14. The conclusion is that the it is satisfactory and realistic according the manual used, because it is recommended that the network error should go towards 0 but it does not need to be 0.0000 . In the current research the error is equal to 0.0006, but it is acceptable because of the higher complexity of $\mathrm{Pi}-\mathrm{ANN}$ with a resolution of matrix $4 \times 4$ compared to the network presented in the bibliographic source with a resolution $3 \times 3$. The entire neural network called Pi-ANN is presented in finished form in Fig. 15.

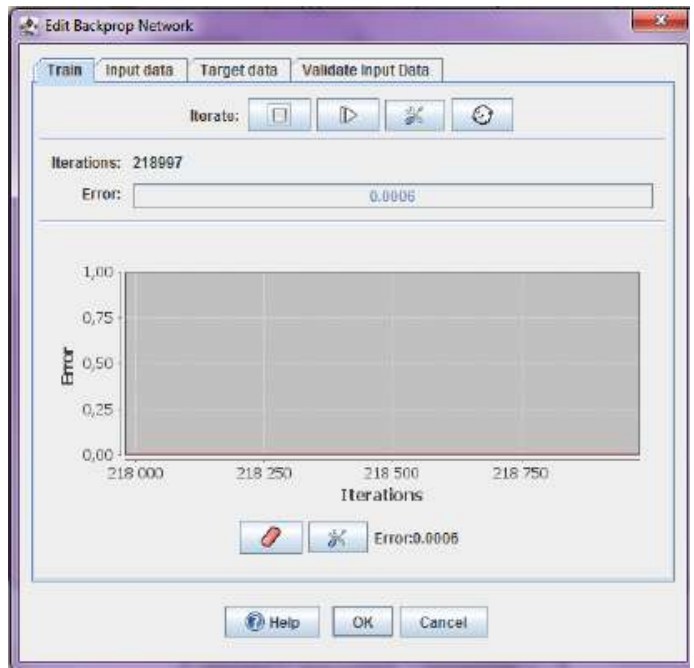

Fig. 14. Backprop neural network called Pi - ANN. 
Годишник Телекомуникации 2020, том 7, с. 71-81

Yearbook Telecommunications 2020, vol. 7, p. 71-81

\section{CONCLUSION}

The pattern recognition of alphabetic characters, phonemes and words can be expanded to sound recognition for the purposes of supporting people with disabilities by improving the conditions of the living environment. In terms of security and especially cybersecurity these technologies must be used carefully and strictly controlled, because of the ability of ANN for self-learning and self-modification.

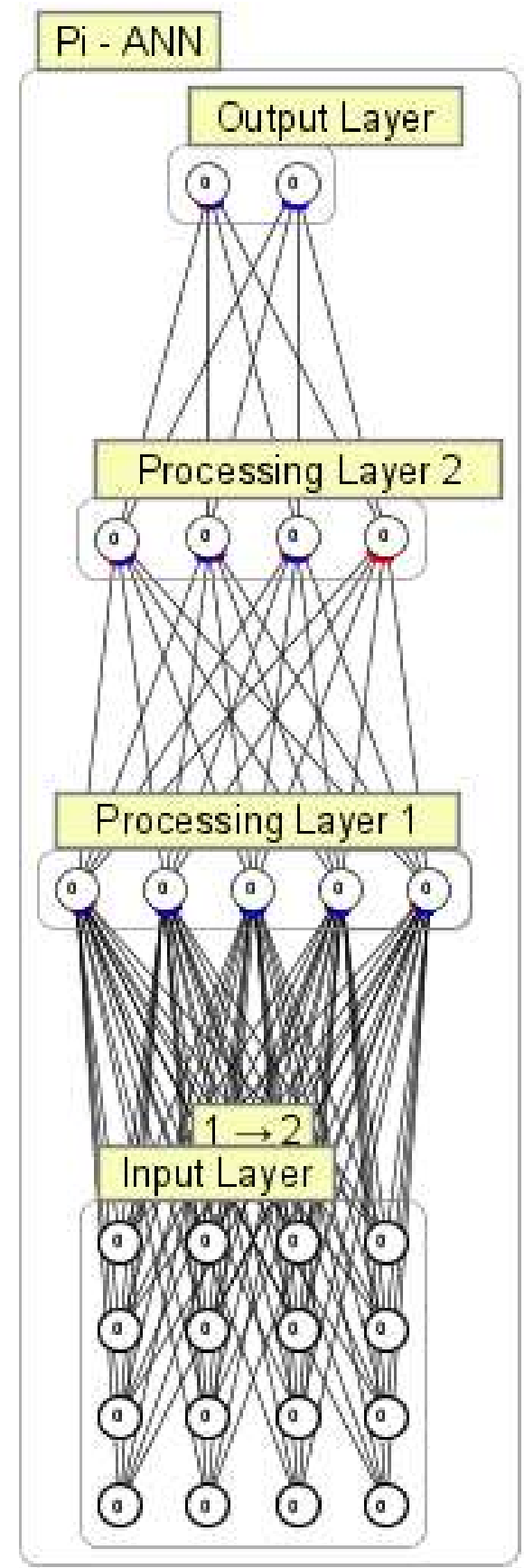

Fig. 15. Backprop neural network called Pi - ANN. 


\section{YOANA IVANOVA}

Actually, the machine learning is an indisputable means of strengthening cybersecurity of terminals, reducing the risks of data loss under the impact of cyberattacks, but in the same time hackers also use machine learning to realize cyberattacks by self-learning bots and another methods.

The development of computer systems and software architectures is directly related to the rise of the hacker culture and the subsequent revolution in the software industry [14]. Attacks in the semantic and syntactic layers are significantly more effective in terms of resources used, organization and implementation time. The "intelligent behavior" of the implemented programs may allow a self-adaptation to specific conditions, applying methods of completion, selfmodification, collaboration with other elements of its type available in the system and adaptive self-preservation mechanisms. The negative consequences can be expressed in full disclosure of encrypted traffic [15].

Actually, the adaptive security must provide sufficient flexibility and accuracy to deal with many of the security issues earlier than the time they were received. There are security manager modules that can manage all secure communications between air and land [16]. The advanced security managers include Intelligent Agents for intrusion detection through intelligent agent technology that is a growing area of research and new application development in telecommunications. A cognitive agent is able to find a solution for a complex problem while communicating with other agents and interacting with its knowledge base. In fact its main capabilities are related to "high reasoning capacity, data processing, perception, learning control, communication and expertise per activity domain" [17].

In conclusion the technological aspects of cybersecurity are expressed in the use of innovative methods and applying advanced tools to prevent cyberattacks in order to reduce negative consequences $[18,19]$. Therefore, these innovations contribute to the technical progress and national security of the countries. In Bulgaria there is an Innovation Council at the Bulgarian Chabmer of Commerce and Industry that supports the development of the artificial intelligence in the field of finance $[20,21]$, because the financial system is one of the sectors of the critical infrastructure and as such needs high level of cybersecurity.

\section{REFERENCES:}

[1] PETROV, Georgi, STANCHEVA, Anushka and Vasil KADREV. Specialized Databases for Spectrum Management Research, Analysis and Forecasting of the Effects of Working Electromagnetic Fields. Yearbook Telecommunications [online]. 2014, (1), pp. 87-96 [viewed 02 June 2021]. eISSN 2534-854X. Available from: https://telecommunications.nbu.bg/bg/godishnik-telekomunikacii

[2] ANDERSON, James A. and Edward ROSENFELD, eds. Talking Nets: An Oral History of Neural Networks. Cambridge, Mass. [u.a.]: The Mit Press, 2000. ISBN 978-026-251-111-7.

[3] MACUKOW, Bohdan. Neural Networks - State of Art, Brief History, Basic Models and Architecture. 15th IFIP International Conference on Computer Information Systems and Industrial Management (CISIM), Sep 2016, Vilnius, Lithuania. pp.3-14, ff10.1007/978-3-319-45378-1_1ff. ffhal-01637477f

[4] WIDROW, Bernard and Michael A. LEHR. Artificial Networks of the Perceptron, Madaline and Backpropagation Family. In: Neurobionics: an interdisciplinary approach to substitute impaired functions of the human nervous system. ed. by Hans-Werner BOTHE. Amsterdam [u.a.], North-Holland, 1993, pp. 133-205. ISBN 0-444-899-588.

[5] Autoassociative memory. Wikipedia [online]. [viewed 02 June 2021]. Available from: https://en.wikipedia.org/wiki/Autoassociative memory

[6] PARK, Young S. and Tae-Soo CHON. Artificial Neural Networks: Temporal Networks. In: Encyclopedia of Ecology. Elsevier B.V., 2008, pp. 245-254. ISBN 978-0-08-045405-4.

[7] NIELSEN, Michael. How the backpropagation algorithm works. In: Neural Networks and Deep Learning [online]. [viewed 03 June 2021]. 2019. Available from: http://neuralnetworksanddeeplearning.com/chap2.html

[8] RUSSEL, Stuart and Peter NORVIG. Artificial Intelligence A Modern Approach. New Jersey: Prentice Hall, 1995. ISBN 0-131-038-052.

[9] MARSALLI, Michael. McCulloch-Pitts Neurons. The Mindproject [online]. [viewed 03 June 2021]. Available from: https://mind.ilstu.edu/curriculum/mcp_neurons/index.html 
Годишник Телекомуникации 2020, том 7, с. 71-81

Yearbook Telecommunications 2020, vol. 7, p. 71-81

eISSN 2534-854X

https://telecommunications.nbu.bg/bg/godishnik-telekomunikacii

DOI: https://doi.org/10.33919/YTelecomm.20.7.9

[10]BRAITENBERG, Valentino. Vehicles: Experiments in Sythetic Psychology. Cambridge, Massachusetts: The MIT Press, 1986. ISBN 978-026-252-112-3.

[11]WIKIPEDIA. Braitenberg vehicle [online]. [viewed 31 March 2021]. Available from: https://en.wikipedia.org/wiki/Braitenberg_vehicle

[12] SIMBRAIN 3.0 Documentation [online]. [viewed 03 June 2021]. Available from: http://simbrain.net/Documentation/docs/SimbrainDocs.html

[13] WHITEHOUSE, Peter. PDub's Simbrain Tutorial. IPT-A Virtual Approach [online]. [viewed 03 June 2021 ]. 2018. Available from: http://www.wonko.info/ipt/iis/ai/simbraintut/index.html

[14]СИМЕОНОВА, Цветелина, Емил ИВАНОВ и Васил КЪДРЕВ. Разработка на симулационен модел за оценка на риска, отчитащ влиянието на осигурителните системи на прелез. Механика, транспорт, комуникации. 2012, (2), с. 1-8. ISSN 1312-3823. Simeonova, Ts., Ivanov, E. i Kadrev, V., Razrabotka na simulatsionen model za otsenka na riska, otchitasht vliyanieto na osiguritelnite sistemi na prelez. Sp. „Mehanika, transport, komunikatsii", statia № 0756, Sofia, 2012, br. 2, ISSN 1312-3823.

[15]КАЛЧЕВ, Камен. Кибервойна - нови аспекти на военната теория. Годишник на Факултет „Команднощзабен“. София: Военна академия „Георги Стойков Раковски“, 2016, (1), с. 60-67. ISSN 1312-2991. ; Kalchev, K., S., Kibervoyna - novi aspekti na voennata teoria, Godishnik na Fakultet „Komandno-shtaben“ (1), Voenna akademia "Georgi Stoykov Rakovski", 2016, ISSN 1312-2991, pp. 60-67.

[16]ПЕНЕЛОВ, Станимир и Камен КАЛЧЕВ. Оценка на киберриск във въздухоплаването. Годишник на Факултет „Командно-щзабен“. София: Военна академия „Георги Стойков Раковски“, 2018, с. 380-392. ISSN 1312-2991.; Penelov, S. and Kalchev, K. Otsenka na kiberrisk vav vazduhoplavaneto, Godishnik na Fakultet „Komandno-shtaben“ (1), Voenna akademia "Georgi Stoykov Rakovski", Sofia, 2018, ISSN 13122991, pp. 380-392.

[17]BOUDAOUD, Karima, LABIOD, Houda, BOUTABA, Raouf and Zahia GUESSOUM. Network Security Management with Intelligent Agents. In: NOMS 2000. 2000 IEEE/IFIP Network Operations and Management Symposium „,The Networked Planet: Management Beyond 2000“. Honolulu, HI, USA: IEEE, 2000, pp. 579592. ISBN 0-7803-5928-3.

[18]НИКОЛОВ, Атанас и Иван ХРИСТОЗОВ. Корпоративна защита на информацията. Подход и решения. Годишник на Военна академия „Георги Стойков Раковски“. София: Институт за перспективни изследвания за отбраната, 2005, с. 205-215. ISSN 1312-0816. ; Nikolov, A. and Hristozov, I. Korporativna zashtita na informaciata. Podhod i reshenia, Voenna academia "Georgi Stojkov Rakovski", Institut za perspektivni izsledvania za otbranata, Sofia, 2005, ISSN 1312-0816, pp. 205-215.

[19]НИКОЛОВ, Атанас и Иван ХРИСТОЗОВ. Проблеми и предизвикателства пред изграждането на национална система за киберсигурност. Военен журнал. 2015, год. 122(3), с. 7-13. ISSN 0861-7392.; Nikolov, A. and Hristozov, I. Problemi i predizvikatestva pred izgravdaneto na nacionalna Sistema za kibersigurnost, Voenen jurnal, 2015, br.3, ISSN 0861-7392, pp.7-13.

[20] АВРАМОВ, Йосиф. Ролята на Съвета по иновации при БТПП за развитието на Финтех (Fin Теch) компаниите и блокчейн технологиите в България. 11-ma международна научна конференция „Еуправление и Е-комуникации”: Сборник трудове. София: Издателство на Технически университет, 2019, c. 137-145. ISSN 1313-8774. ; Avramov, Yosif. Rolyata na Saveta po inovatsii pri BTPP za razvitieto na Finteh (Fin Tech) kompaniite i blokcheyn tehnologiite v Bulgaria; Yosif Avramov; Izdatelstvo na Tehnicheski universitet-Sofia, 11-ta mezhdunarodna nauchna konferentsia „E-upravlenie i E-komunikatsii”, Sbornik trudove, Sofia, 2019; ISSN 1313-8774, pp.137-145.

[21] AVRAMOV, Yosif. Development and prospects for Fin Tech companies blockchains technolodgies in Bulgaria and Eastern Eurrope. Yearbook of the Faculty of Economics and Business Administration. Sofia: University „St Kliment Ohridski“, 2020, vol. 19(1), pp. 243-247. ISSN 1311-8420.

\section{Contacts:}

Assistant Yoana Atanasova Ivanova, PhD, New Bulgarian University, Department Telecommunication, Sofia, 21 Montevideo St., e-mail: yivanova@nbu.bg

Date of receipt of the manuscript: 18.09.2020

Date of adoption for publication: 27.09.2020 